\title{
Inequality in Latin America: a global measurement
}

\section{Verónica Amarante, Marco Galván and Xavier Mancero}

ABSTRACT

This article combines individual data from household surveys in the Latin American countries to obtain a regional income vector and analyse its distribution and recent changes. It investigates whether distributive changes in the countries over the past decade have improved income distribution between individuals or widened gaps. The region's indicators of global inequality declined significantly during 2003-2012. This drop in global inequality is explained essentially by the reduction of inequality within Latin American countries. The incomes of the inhabitants of Latin America are now more equal in relative terms than a decade ago, although differences in the countries' average incomes have increased.

KEYWORDS

JEL CLASSIFICATION

AUTHORS
Economic development, social development, incomes, income distribution, equality, socioeconomic indicators, Latin America

D31, I3, O57

Verónica Amarante is chief of the Economic Commission for Latin America and the Caribbean (EcLAC) office in Montevideo, Uruguay. veronica.amarante@cepal.org

Marco Galván is a research assistant with the Statistics Division of the Economic Commission for Latin America and the Caribbean (ECLAC). marco.galvan@cepal.org

Xavier Mancero is chief of the Social Statistics Unit of the Statistics Division of the Economic Commission for Latin America and the Caribbean (ECLAC).xavier.mancero@cepal.org 


\section{I}

\section{Introduction}

The study of inequality has long been central to research on Latin American countries, especially since they have figured among the world's most unequal for as long as reliable statistics based on microdata have been available (see, for example, Alvaredo and Gasparini, 2015). A number of studies on inequality in Latin America have concentrated on inequalities within countries, and in this way there has grown up a large literature (summarized in section II of this article) studying inequality from different perspectives and seeking to understand its determinants and evolution, focusing on the reversal of the upward trend of income inequality in the region since 2002.

A question that has been raised less often in relation to Latin America, though, is how different the incomes of the region's inhabitants are when the region is considered globally, and how this inequality has evolved over the last decade, during which inequality has diminished in most of the region's countries. This article aims to address that question, since it is relevant to complete the diagnosis of the recent evolution of inequality in Latin America. With this in view, different indicators for the evolution of individual incomes in the region as a whole are presented, with the evolution of inequality in particular being analysed. The article seeks to ascertain whether distributive changes within the region's countries over the past decade have been matched by improvements in income distribution between Latin Americans, or whether gaps have widened. The analysis is based on a combination of data from household surveys in the region, using similar criteria to process the data from the different countries, and specifically to calculate household incomes, so that the resulting vector is consistent between countries.

The article is organized as follows. After this Introduction, section II presents a brief overview of developments in the discussion and measurement of global inequality in the literature. Section III summarizes the evolution of inequality within the different countries of the region in recent years, together with the explanations put forward for this. Section IV presents the data used in the article and describes the methodologies chosen to measure inequality at the regional level. After this, the main findings of this study are set forth: section V discusses average income differences in the region, and section VI shows the evolution of the incomes of Latin Americans and their distribution, comparing information from the early 2000s (specifically 2003, when the inequality trend changed in most of the region's countries) with the most recent information available, which is for 2012. Lastly, section VII offers some final comments.

The authors are grateful to Marcela Gómez for her work as research assistant in the preparation of this article.

\section{II}

\section{Global inequality}

The importance of studying inequality can be argued for on grounds originating in theories of social justice, and also on purely instrumental grounds of economic efficiency. Concern about inequality stemming from considerations of social justice has not gone undebated (Feldstein, 1999; Milanovic, 2007, among others), and one of a number of moot issues is whether the real concern is inequality of opportunity (as suggested by Roemer, 1998) or inequality of outcomes, including income. In a recent publication, Atkinson (2015) gives three reasons for economics to remain concerned about the distribution of outcomes, including income. First, on moral grounds, the situation of the most disadvantaged individuals cannot be ignored, even in the 
hypothetical event that equality of opportunities were guaranteed. ${ }^{1}$ Furthermore, the structure of final prices or returns is so unequal that it warrants concern about outcomes, while also accounting for the consensus over the need to ensure equality of opportunities. Lastly, inequality of outcomes in the present affects equality of opportunities for future generations. Concerns about limited social mobility and the need to ensure equality of opportunities mean there is a need to reduce inequality of outcomes in the present. If the purely instrumental arguments are considered, the empirical debate and controversy centre on the link between income inequality and economic growth, and more specifically on the potential adverse effects of inequality on growth via a number of channels that include political economy, conflict and capital market flaws, among other things (see, for example, Alesina and Rodrik, 1994; Alesina and Perotti, 1996; Persson and Tabellini, 1994; Barro, 2000).

For the reasons given, it is important to study inequality. The result has been a large literature, usually focusing on developments in one country or comparisons between countries. However, some studies have concentrated on analysing global inequality. According to Milanovic (2005), it is possible to distinguish three different concepts used in the effort to capture inequality at the world level. The first is found in the oldest studies on this issue, which estimated global inequality by considering the level that would prevail if the world were populated by representative individuals from each country, each receiving their country's average income. This is known as the international inequality approach, and basically consists in comparing average incomes in the different countries without weighting them by their respective populations. The second concept also addresses international inequality, but considers differences in country size, yielding an indicator similar to the first one but weighted by each country's population. The third concept deals with what is known as global inequality and restores the individual as the unit of analysis, ignoring national borders. This is the approach applied in this study, which seeks to capture income differences between individuals in the region.

A number of studies have sought to engage with this third concept, which reflects global inequality, by

\footnotetext{
${ }^{1}$ In the words of Milanovic (2007), the income of others enters each person's utility function, so that high levels of inequality affect individual welfare, although he acknowledges the possibility that individuals might be motivated by good feelings, like the subjects referred to by Atkinson (2015), or by bad feelings such as envy.
}

deriving worldwide distribution from per capita gross domestic product (GDP) data and summary measures of inequality within countries (Schultz, 1998) or combining information from household surveys and per capita GDP data (Berry, Bourguignon and Morrison, 1983; Bourguignon and Morrison, 2002; Sala-i-Martin, 2006, among others). Other studies have examined global inequality on the basis of information from household surveys alone, deriving worldwide income distribution from these (Milanovic, 2005).

More recent studies on global inequality in recent decades (Milanovic, 2012; Lakner and Milanovic, 2013; Niño-Zarazúa, Roope and Tarp, 2014; Anand and Segal, 2015) combine information from household surveys and consider quantiles of income distribution (usually ventiles) in each country, imputing the average per capita income to each quantile and constructing a database containing the quantiles of the world's different countries. ${ }^{2}$ These studies all agree that the level of global inequality is very high, comparable indeed to that of the world's most unequal countries, and that it presents relatively minor variations over time.

As regards regional inequality, Gasparini and others (2008) report that, when household survey data from the region are combined, global inequality is found to have followed much the same pattern as inequality within countries: an increase in the 1990s and a decline from the early years of the 2000s. ${ }^{3}$ Another study dealing with Latin America is Gasparini and Gluzmann (2012), which uses information from the 2006 Gallup World Poll, conducted in 132 countries that year. Although these polls do not capture income as accurately as household surveys, they can be used to analyse global inequality. The authors estimate indicators of inequality by region, finding the Gini coefficient for Latin America to be 0.525 in 2006, a much higher figure than for Western Europe (0.402), North America (0.438) or Eastern Europe and Central Asia (0.497). However, inequality was lower in the Latin America region than in South Asia (0.534), the Caribbean (0.591) or East Asia and Asia and the Pacific (0.594). The authors argue that Latin America is composed of countries with high and similar levels of inequality, but that taken as a whole the region is not the world's most unequal. Although Latin American countries

\footnotetext{
2 Quantiles are points taken at regular intervals in the distribution function of a random variable. By way of example, when the income distribution is divided into 20 groups, they are called ventiles. Thus, the first ventile contains the poorest $5 \%$ of individuals.

3 These estimates are for 12 countries in the 1990-2006 period.
} 
are highly unequal in relative terms, the dispersion of income between them is smaller than in other regions of the world.

Among the main aspects deemed by Anand and Segal (2008) to justify the study of global inequality are moral factors and also the consequences that can ensue from global inequality. With regard to the former, the disparities between individual incomes at the global level can be considered unfair, and this is a reason for analysing how different individuals' incomes are when considered globally and not in relation to their nationality. ${ }^{4}$ On the other hand, evidence on inequality at the world level is interesting for the scope it provides to analyse the predictive power of theories: according to neoclassical growth theory, incomes between countries and indeed between individuals should converge in the long run, while dependency theory predicts divergence.

Studies on global inequality have been motivated essentially by the need to assess the extent to which globalization, while perhaps increasing inequality within

\footnotetext{
${ }^{4}$ Here, Milanovic (2015) argues that, by being born in a particular country, people receive two "public goods": the country's average income and the inequality of its distribution. Over half the variability of global income is explained by circumstances of birth, including average income and income inequality in the country of birth.
}

countries, might also have caused it to decline at the global level. This would mean that differences between individuals around the world were growing smaller, and could be the result of poorer (and more populous) countries having grown more quickly than richer (and less populous) ones. These studies also set out to analyse whether the rules governing the interactions between rich and poor countries impact global inequality. The more integration there is between countries, the more factor mobility there is across borders and the more the perceptions and aspirations of a given country's people are influenced by the living conditions of other countries'. All these aspects make inequality an issue of relevance beyond national borders.

In a global inequality analysis covering the countries of Latin America, the focus of interest is not the linkages between the consequences of globalization and inequality, as when the world as a whole is considered, since the bulk of trade and financial flows takes place between the region and the world rather than within the region, and could be affecting all the countries similarly. The main interest lies in understanding the relative situation of individuals in the region and showing the extent to which the recent decline in income inequality in most of the region's countries has been accompanied by convergence or divergence in individual welfare at the regional level.

\section{III}

\section{The recent evolution of inequality in the countries of Latin America}

Income inequality indicators in Latin America have shifted substantially in the last 10 years. Since 2002 or 2003 (depending on the country), levels of income inequality have been dropping in most of the region's countries. The changes have been gradual and all but imperceptible from one year to the next, but come out clearly when longer periods are compared. If the 2002-2012 period is taken, Gini coefficients declined, indicating improvements in distribution, in 16 of the 17 countries included in this study (see figure 1). The exception is Costa Rica, whose Gini coefficient was higher in 2012 than in 2002. This recent downward trend is statistically significant and has taken place in a context of sustained economic growth and poverty reduction in the region. The downward trend in inequality has gathered pace since 2008 (ECLAC, 2013).

The changes revealed by the decline in Gini coefficients have also been reflected in the share of total income going to the top and bottom quintiles. ${ }^{5} \mathrm{In}$ most of the countries (the exceptions are the Dominican

\footnotetext{
${ }^{5}$ The figures cited for the quintile shares refer to quintiles of households ranked by per capita income.
} 
Republic, Paraguay and Honduras), the share of total income going to the poorest quintile increased between 2002 and 2012 (see figure 2). At the other extreme, the share of the richest quintile fell in almost all the countries, the exception being Paraguay (see figure 3 ). The most recent data available indicate that the poorest quintile (i.e., the lowest-income $20 \%$ of households) receives an average of 5\% of total income, with the share ranging from $4 \%$ in the Dominican Republic, Honduras and Paraguay to $10 \%$ in Uruguay, while the share of total income going to the richest quintile averages $47 \%$, ranging from $35 \%$ in Uruguay to 55\% in Brazil (ECLAC, 2013).

This change in the trend of income inequality has been interpreted in various ways. Labour income, the main source of household income, has driven this decline in inequality. Notwithstanding the positive repercussions of rising employment, falling dependency ratios and redistributive cash transfers, the factor that accounts for most of the decline of income inequality has been the narrowing of the wage differential between skilled and unskilled workers (ECLAC, 2012).

The decline in the skill premium, as manifested in narrowing differentials relative to the group without education, evinces a clear and consistent pattern across countries (see figure 4). At the same time, education levels in the population (and among those in work) have risen. However, it is difficult to gauge whether the evolution of this wage differential is mainly due to changes in the relative demand for skilled workers or changes in the relative supply. While some authors have stressed the importance of the increase in the relative supply of skilled workers (López-Calva and Lustig, 2010; Azevedo and others, 2013), others have emphasized the possible role of higher relative demand for unskilled workers in the context of an increasing supply of skilled labour (Gasparini and others, 2012; De la Torre, Messina and Pienknagura, 2012).

FIGURE 1

Latin America (18 countries): Gini coefficient, around 2002 and 2012

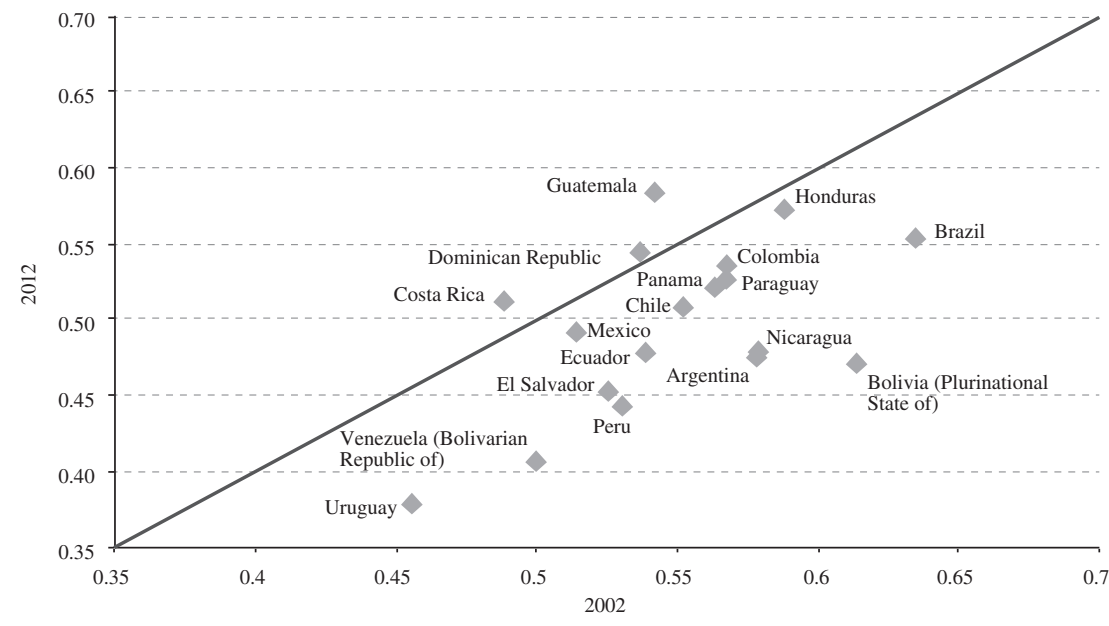

Source: Prepared by the authors, on the basis of Economic Commission for Latin America and the Caribbean (ECLAC), CEPALSTAT database. 
FIGURE 2

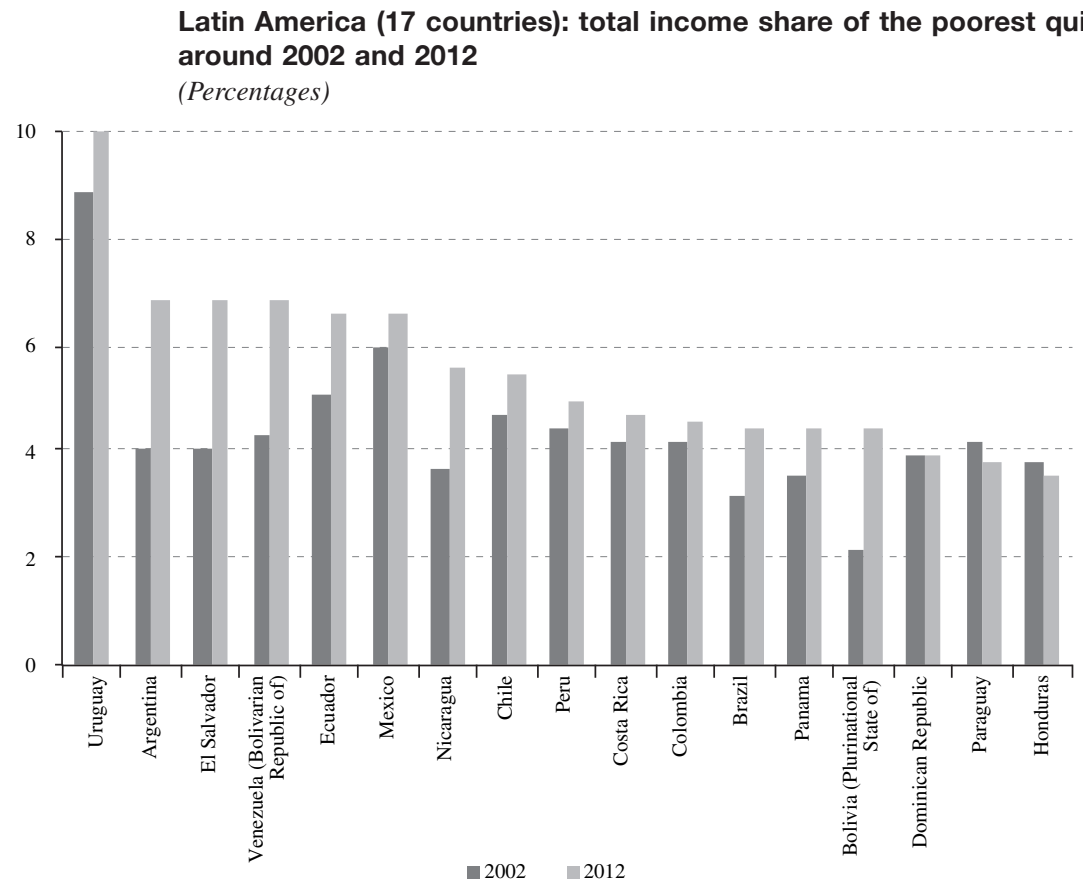

Source: Economic Commission for Latin America and the Caribbean (ECLAC), Social Panorama of Latin America 2013 (LC/G.2580), Santiago, 2013.

FIGURE 3

Latin America (17 countries): total income share of the richest quintile, around 2002 and 2012

(Percentages)

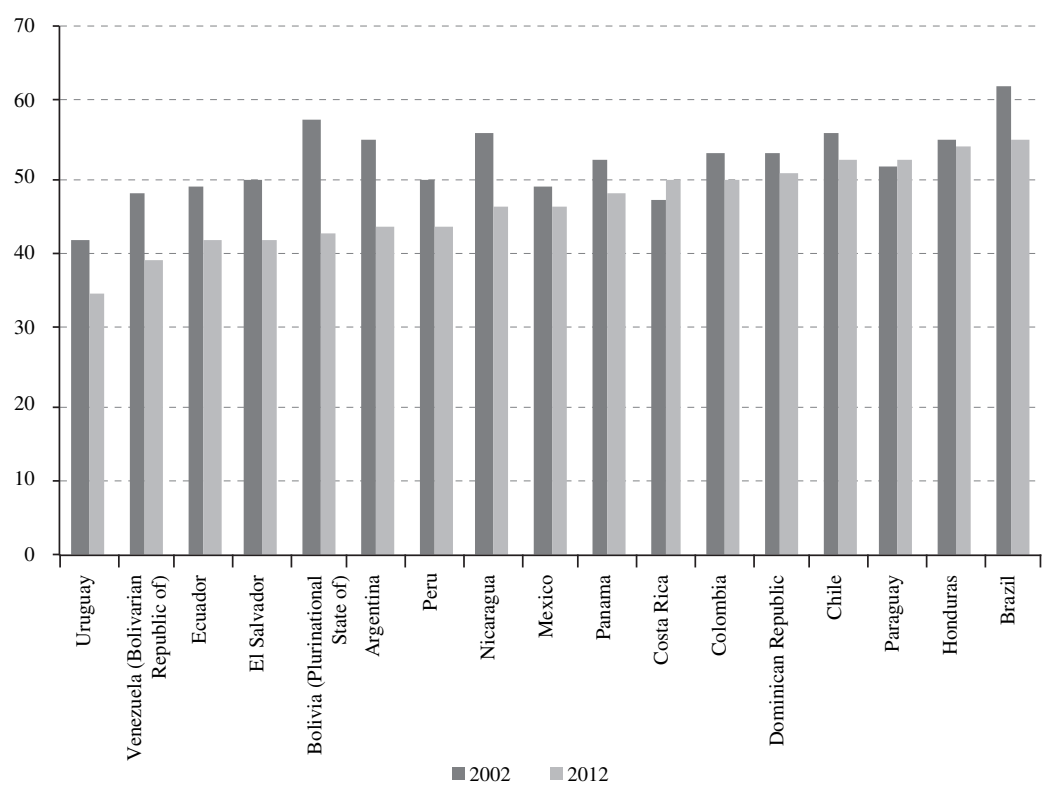

Source: Economic Commission for Latin America and the Caribbean (ECLAC), Social Panorama of Latin America 2013 (LC/G.2580), Santiago, 2013. 
FIGURE 4

Latin America (18 countries): skill premium relative to the group with no education, 2002 and 2011

(Percentages)

A. Complete secondary education

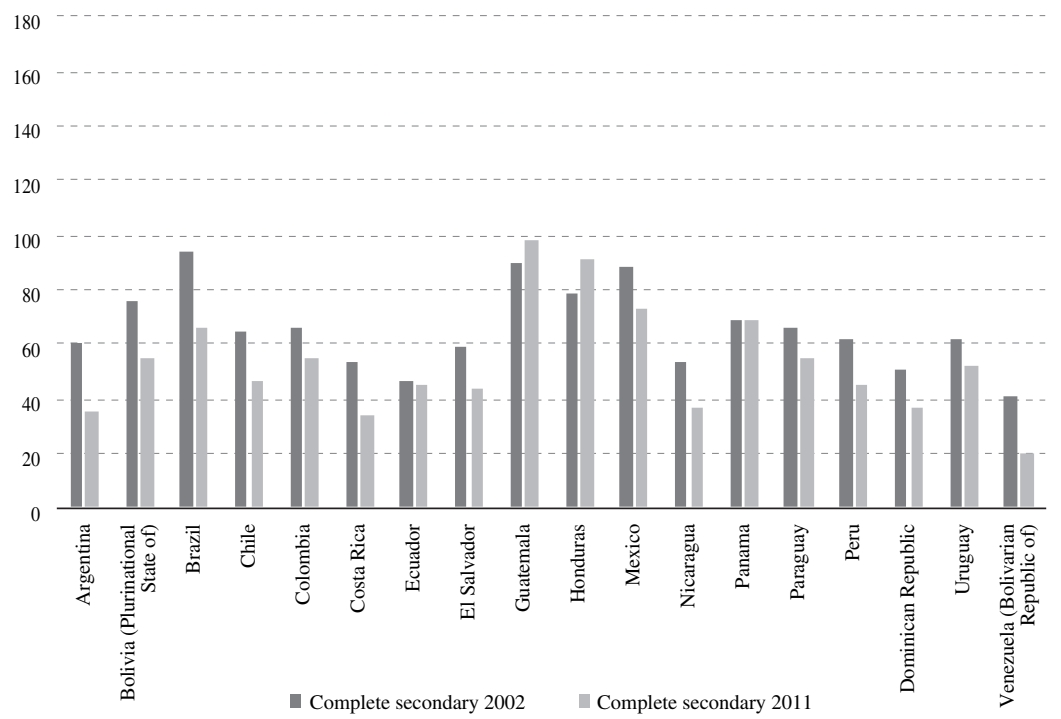

B. Tertiary education

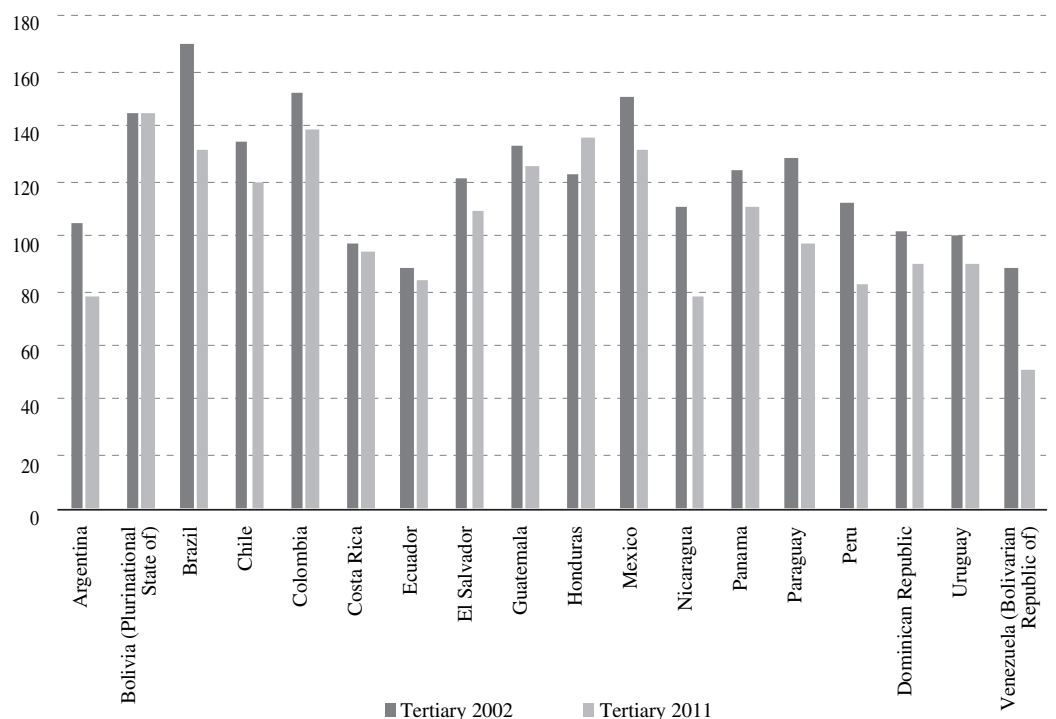

Source: Economic Commission for Latin America and the Caribbean (ECLAC), Compacts for Equality: Towards a Sustainable Future (LC/G.2586(SES.35/3)), Santiago, 2014. 
These distributive changes have taken place in a different political context to that of earlier decades. Democratic life has resulted in new electoral preferences and greater prominence for social demands. One consequence has been that, in a positive cycle of economic stability, governments have responded to these demands for social inclusion with policies of a more redistributive cast (Roberts, 2014). Other authors have preferred to speak of reforms inspired by the idea of "prudent redistribution with growth" (Cornia, 2010), involving progressive fiscal, labour and transfer policies. Redistributive policies and social reforms have not been the exclusive preserve of left-wing governments in the region. Rather, the institutionalization of electoral competition in contexts of high economic and social inequality seems to have led parties and governments of different ideological hues to strive to meet popular demands for equality and social inclusion (Roberts, 2014).

Thus, improved distribution may well be the most distinctive feature of the last decade in Latin America. This article will now go on to analyse whether these distributive changes within the region's countries over the last decade have been accompanied by any improvement in the income distribution between Latin Americans, or whether gaps have widened.

\section{IV}

\section{Data for calculating regional inequality}

To estimate regional inequality, a database was constructed out of a combination of variables from household surveys in 18 countries of the region at two points in time, around 2002 and around 2012. 6 These 18 countries contain $96 \%$ of the total population of Latin America. Details of sample sizes, population distribution by country and survey years can be found in table 1 . The essential variables taken from these surveys are those relating to household income, and they have been standardized by the Economic Commission for Latin America and the Caribbean (ECLAC) so that they can be used to estimate factors like the incidence of poverty in the region. ${ }^{7}$ Two income vectors are considered. The first is per capita household income, corrected for estimated survey nonresponse and adjusted for purchasing power parity (PPP). ${ }^{8}$

\footnotetext{
${ }^{6}$ Haiti and Cuba were not included in the analysis because the necessary information sources are not available.

${ }^{7}$ Another way of capturing household welfare is to consider household consumption rather than income. Income and spending surveys, which measure consumption spending by households, are also carried out periodically in the region. They are not available at the same points in time for a large set of countries, however, whereas household surveys are.

${ }^{8}$ Incomes were taken up to 2005 by considering the change in each country's general consumer price index (CPI) so that the PPP factors estimated for that year could be applied. In the case of Argentina, a simple average of price indices from five provinces was used as the deflator from 2007 onward. See World Bank, World Development Indicators [online] http://data.worldbank.org/data-catalog/worlddevelopment-indicators.
}

As an alternative way of equalling out households' purchasing power and so enabling the robustness of the results to be analysed, the poverty lines calculated by ECLAC to estimate regional poverty are used as price deflators. These lines represent the cost of purchasing a basket of staple foods and goods required to meet other basic needs, and can therefore be assumed to reflect differences in the cost of attaining a similar level of well-being across countries. To maintain consistency with the way these lines are employed by ECLAC to calculate poverty, use is made in this case of the per capita household income vector adjusted to national accounts values (see ECLAC, 2013). $9^{9}$

It is important to stress that the choice of price vector for carrying out comparisons between countries is an important methodological step. Measurements of global inequality and poverty are sensitive to the price vector used to compare incomes across countries (Chen and Ravallion, 2010; Ravallion, Chen and Sangraula, 2009; Milanovic, 2012). The new PPP vector for 2005 , calculated by the International

\footnotetext{
${ }^{9}$ There are two databases that compile household surveys from the region, constructing standardized income variables for the different countries. One is the ECLAC database, which the present study relies on, and the other is the Socio-Economic Database for Latin America and the Caribbean (SEDLAC) maintained by the Centre for Distributive, Labour and Social Studies (CEDLAS) of the National University of La Plata and the World Bank.
} 
Comparison Programme, involved higher price estimates for most poor countries, with the result that global inequality levels were calculated to be over five points higher than with the previous PPP vector
(Milanovic, 2012). As will be seen later, the results presented in this article are robust to both of the price vectors used in the study to carry out comparisons between countries.

TABLE 1

Latin America: household survey sample sizes and populations ${ }^{a}$

\begin{tabular}{|c|c|c|c|c|c|c|}
\hline Around 2002 & $\begin{array}{l}\text { Sampling cases } \\
\text { (thousands) }\end{array}$ & $\begin{array}{c}\text { Percentage } \\
\text { distribution of } \\
\text { sampling cases }\end{array}$ & $\begin{array}{l}\text { Expanded cases } \\
\text { (thousands) }\end{array}$ & $\begin{array}{c}\text { Percentage } \\
\text { distribution of } \\
\text { expanded cases }\end{array}$ & $\begin{array}{l}\text { Population } \\
\text { (thousands) }\end{array}$ & $\begin{array}{c}\text { Percentage } \\
\text { distribution } \\
\text { of population }\end{array}$ \\
\hline Argentina 2002 & 22832 & 4 & 24546 & 5 & 36906 & 7 \\
\hline \multicolumn{7}{|l|}{ State of) 2002} \\
\hline Brazil 2002 & 105984 & 20 & 173104 & 36 & 174506 & 33 \\
\hline Chile 2000 & 65007 & 13 & 15033 & 3 & 15455 & 3 \\
\hline Colombia 2002 & 129164 & 25 & 39767 & 8 & 39900 & 8 \\
\hline Costa Rica 2002 & 11094 & 2 & 3991 & 1 & 3930 & 1 \\
\hline Dominican Republic 2002 & 5720 & 1 & 8553 & 2 & 8575 & 2 \\
\hline Ecuador 2002 & 6030 & 1 & 8288 & 2 & 12567 & 2 \\
\hline El Salvador 2001 & 11953 & 2 & 6415 & 1 & 5959 & 1 \\
\hline Guatemala 2002 & 2759 & 1 & 11556 & 2 & 11204 & 2 \\
\hline Honduras 2002 & 22010 & 4 & 6668 & 1 & 6236 & 1 \\
\hline Mexico 2002 & 17167 & 3 & 101522 & 21 & 101721 & 20 \\
\hline Nicaragua 2001 & 4191 & 1 & 5193 & 1 & 5101 & 1 \\
\hline Panama 2002 & 13404 & 3 & 2991 & 1 & 3053 & 1 \\
\hline Paraguay 2001 & 8131 & 2 & 5333 & 1 & 26004 & 5 \\
\hline Peru 2001 & 16515 & 3 & 26660 & 6 & 5350 & 1 \\
\hline Uruguay 2002 & 18421 & 4 & 2678 & 1 & 3321 & 1 \\
\hline Venezuela (Bolivarian & 53124 & 10 & 25767 & 5 & 24408 & 5 \\
\hline \multicolumn{7}{|l|}{ Republic of) 2002} \\
\hline Latin America & 519252 & 100 & 476556 & 100 & 521429 & 100 \\
\hline \multicolumn{7}{|l|}{ Around 2011} \\
\hline Argentina 2012 & 69293 & 10 & 25351 & 5 & 40370 & 7 \\
\hline \multicolumn{6}{|l|}{ State of) 2011} & 2 \\
\hline Brazil 2012 & 114906 & 16 & 196723 & 36 & 195153 & 33 \\
\hline Chile 2011 & 59084 & 8 & 16941 & 3 & 17149 & 3 \\
\hline Colombia 2012 & 228662 & 33 & 45029 & 8 & 46448 & 8 \\
\hline Costa Rica 2012 & 11374 & 2 & 4661 & 1 & 4669 & 1 \\
\hline Dominican Republic 2012 & 8163 & 1 & 10077 & 2 & 9907 & 2 \\
\hline Ecuador 2012 & 19840 & 3 & 14676 & 3 & 15018 & 3 \\
\hline El Salvador 2012 & 21710 & 3 & 6245 & 1 & 6218 & 1 \\
\hline Guatemala 2006 & 13686 & 2 & 12966 & 2 & 14334 & 2 \\
\hline Honduras 2010 & 7043 & 1 & 8041 & 1 & 7619 & 1 \\
\hline Mexico 2012 & 9002 & 1 & 117284 & 21 & 115301 & 20 \\
\hline Nicaragua 2009 & 6515 & 1 & 5755 & 1 & 5813 & 1 \\
\hline Panama 2011 & 12379 & 2 & 3624 & 1 & 3676 & 1 \\
\hline Paraguay 2011 & 4894 & 1 & 6465 & 1 & 29272 & 5 \\
\hline Peru 2012 & 25091 & 4 & 30533 & 6 & 6458 & 1 \\
\hline Uruguay 2012 & 43839 & 6 & 3373 & 1 & 3373 & 1 \\
\hline Venezuela (Bolivarian & 37643 & 5 & 28819 & 5 & 29039 & 5 \\
\hline \multicolumn{7}{|l|}{ Republic of) 2012} \\
\hline Latin America & 701975 & 100 & 547256 & 100 & 590082 & 100 \\
\hline
\end{tabular}

Source: Prepared by the authors, on the basis of data from household surveys in the respective countries and Latin American and Caribbean Demographic Centre (CELADE) - Population Division of EClaC, Population database.

${ }^{\text {a }}$ Further details on the databases used can be found at [online] http://interwp.cepal.org/badehog/acercade.asp. 


\section{The average incomes of Latin Americans}

An initial approach to GDP and average incomes in the region's countries brings some major differences to light (see table 2). The ranking of the countries is similar in both cases, although not identical (see figure 5). If data from 2011 are taken, Chile is the country with the highest per capita GDP in the region (US\$21,011 a year at PPP), while Uruguay has the highest per capita household income (US\$ 554 a month at PPP).

The per capita GDP ratio between the richest country and the poorest (Chile and Nicaragua, respectively) rose from 4.0 to 5.5 between 2002 and 2011. Average differences in per capita household income have also widened, with the ratio rising from 3.0 in 2002 (between Chile and Nicaragua) to 3.7 in 2012 (between Uruguay and Nicaragua). Chile is the country with the highest ratio between per capita household income and the poverty line (3.6 in the starting year and 4.2 in the end year), while this ratio is lowest in Honduras ( 0.9 and 1.0 in the starting and end years, respectively). The ratio between the highest and lowest per capita incomes relative to the poverty line fell over the period. The coefficient of variation of the three variables increased over the period (albeit only slightly in the case of income relative to the poverty line).

Latin America: per capita gross domestic product (GDP) and household income, 2002, 2011 and 2012

\begin{tabular}{|c|c|c|c|c|c|c|}
\hline & \multicolumn{2}{|c|}{$\begin{array}{c}\text { Per capita GDP } \\
\text { (in } 2005 \text { PPP dollars) }\end{array}$} & \multicolumn{2}{|c|}{$\begin{array}{l}\text { Per capita household income } \\
\quad \text { (in 2005 PPP dollars })^{\mathrm{b}} \\
(\text { monthly) }\end{array}$} & \multicolumn{2}{|c|}{ 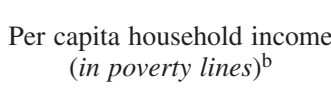 } \\
\hline & 2002 & 2011 & 2002 & 2012 & 2002 & 2012 \\
\hline Argentina $^{\mathrm{a}}$ & 7948 & & 281 & 482 & 2.1 & 3.7 \\
\hline Bolivia (Plurinational State of) & 3229 & 4936 & 189 & 273 & 1.4 & 1.9 \\
\hline Brazil & 7395 & 11515 & 316 & 445 & 3.0 & 4.2 \\
\hline Chile & 10413 & 21001 & 363 & 427 & 3.6 & 4.2 \\
\hline Colombia & 6154 & 9973 & 213 & 311 & 1.8 & 2.4 \\
\hline Costa Rica & 7491 & 12074 & 327 & 433 & 3.0 & 3.3 \\
\hline Dominican Republic & 5539 & 9617 & 247 & 228 & 1.8 & 2.0 \\
\hline Ecuador & 5954 & 9155 & 290 & 311 & 1.7 & 2.0 \\
\hline El Salvador & 4920 & 6785 & 228 & 189 & 1.5 & 1.4 \\
\hline Guatemala & 3717 & 4914 & 189 & 223 & 1.3 & 1.6 \\
\hline Honduras & 2724 & 4031 & 174 & 171 & 0.9 & 1.0 \\
\hline Mexico & 10361 & 16044 & 305 & 335 & 2.0 & 1.9 \\
\hline Nicaragua & 2572 & 3797 & 143 & 151 & 1.1 & 1.2 \\
\hline Panama & 7190 & 14756 & 318 & 356 & 2.4 & 3.0 \\
\hline Paraguay & 4025 & 6112 & 252 & 333 & 1.3 & 1.6 \\
\hline Peru & 5219 & 10076 & 190 & 304 & 1.4 & 2.2 \\
\hline Uruguay & 7819 & 14970 & 430 & 554 & 3.1 & 3.7 \\
\hline Venezuela (Bolivarian Republic of) & 7997 & 12534 & 172 & 289 & 1.6 & 2.2 \\
\hline Simple average & 6148 & 10135 & 257 & 323 & 1.9 & 2.4 \\
\hline Highest & 10413 & 21001 & 430 & 554 & 4 & 4 \\
\hline Lowest & 2572 & 3797 & 142.74 & 151.4 & 0.9 & 1 \\
\hline Ratio highest/lowest & 4.0 & 5.5 & 3.0 & 3.7 & 4.3 & 4.0 \\
\hline Coefficient of variation & 0.39 & 0.47 & 0.30 & 0.35 & 0.40 & 0.42 \\
\hline
\end{tabular}

Source: Prepared by the authors, on the basis of World Bank, World Development Indicators, and household survey data from the respective countries.

a Per capita GDP figures in PPP have not been published for Argentina since 2007.

b The 2002 figures include data from 2000 in Chile and from 2001 in El Salvador, Nicaragua, Paraguay and Peru. The 2012 figures include data from 2011 in Chile, Panama, Paraguay and the Plurinational State of Bolivia, 2010 in Honduras and 2006 in Guatemala. 
FIGURE 5

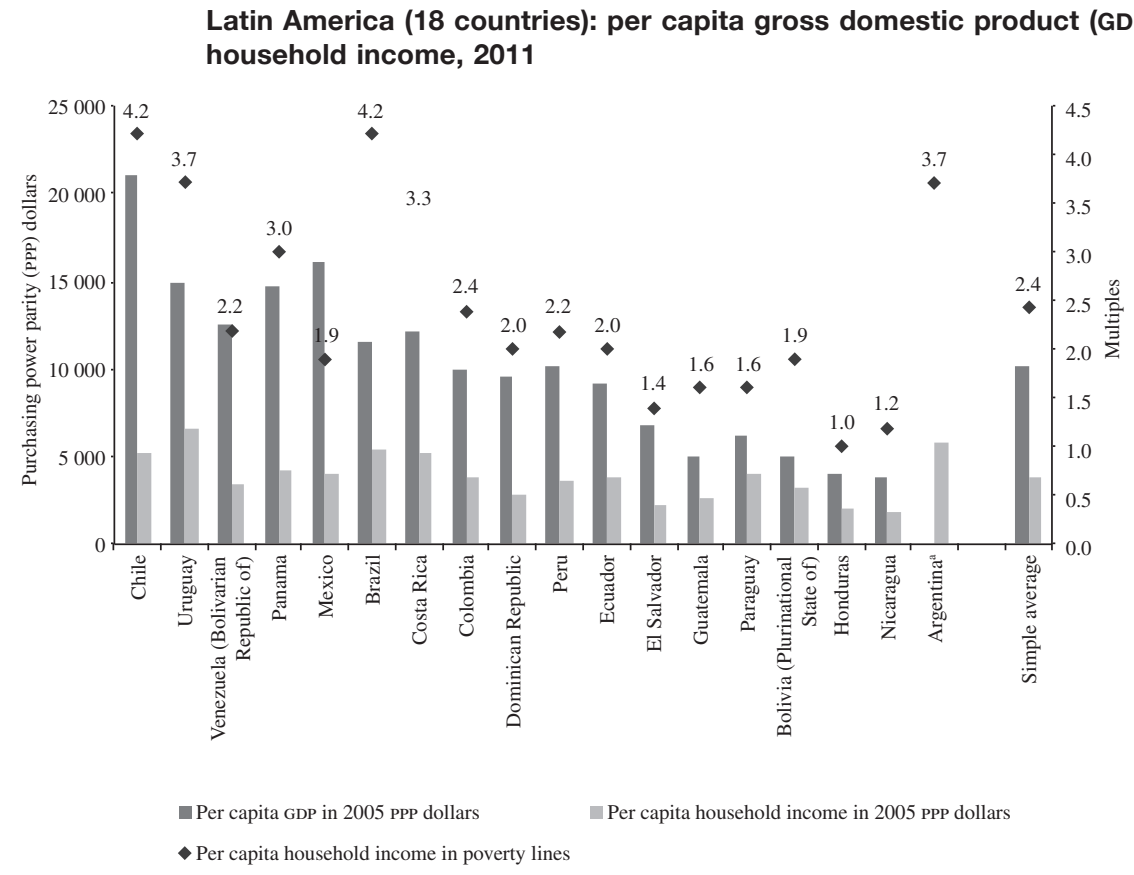

Source: Prepared by the authors, on the basis of World Bank, World Development Indicators, and household survey data from the respective countries.

a Per capita GDP figures in PPP have not been published for Argentina since 2007.

The widening of average differences in per capita GDP and income between the region's countries, then, does not support the idea that the average situation is one of convergence between them. As will be seen in the following section, though, if the borders between countries are ignored and individuals are taken as the unit rather than country averages, the differences have narrowed.

\section{VI}

\section{Income distribution between Latin Americans}

The analysis of global inequality uses the traditional statistical tools employed to analyze income inequality between households at a national level. As discussed earlier, the first step is to construct an income vector that is comparable across the region's countries. The results presented below were obtained by considering income values in PPP dollars. The results obtained using the ECLAC poverty line as the measurement unit are given in the annex, since they are generally similar to those shown below.

The distribution of the countries' populations within these global quintiles is an initial indicator of the income differences between countries (see figure 6 and table A. 1 of the annex). In countries such as Argentina, Brazil, Chile, Costa Rica and Uruguay, over half the population is in the top two quintiles of the regional distribution. At the other extreme, over half the population in El Salvador, Guatemala, Honduras and Nicaragua (and to a lesser extent the Dominican Republic, Mexico and the Plurinational State of Bolivia) is in the bottom two quintiles of the regional distribution. As was to be expected, the larger countries, which weigh more heavily in the construction of the quintiles, have more homogeneously distributed populations. The results obtained when incomes are compared using the poverty line as the unit of measurement are similar (see table A.2 of the annex). 
FIGURE 6

Latin America (18 countries): distribution of the countries' populations by income quintiles, around 2012

(Percentages)

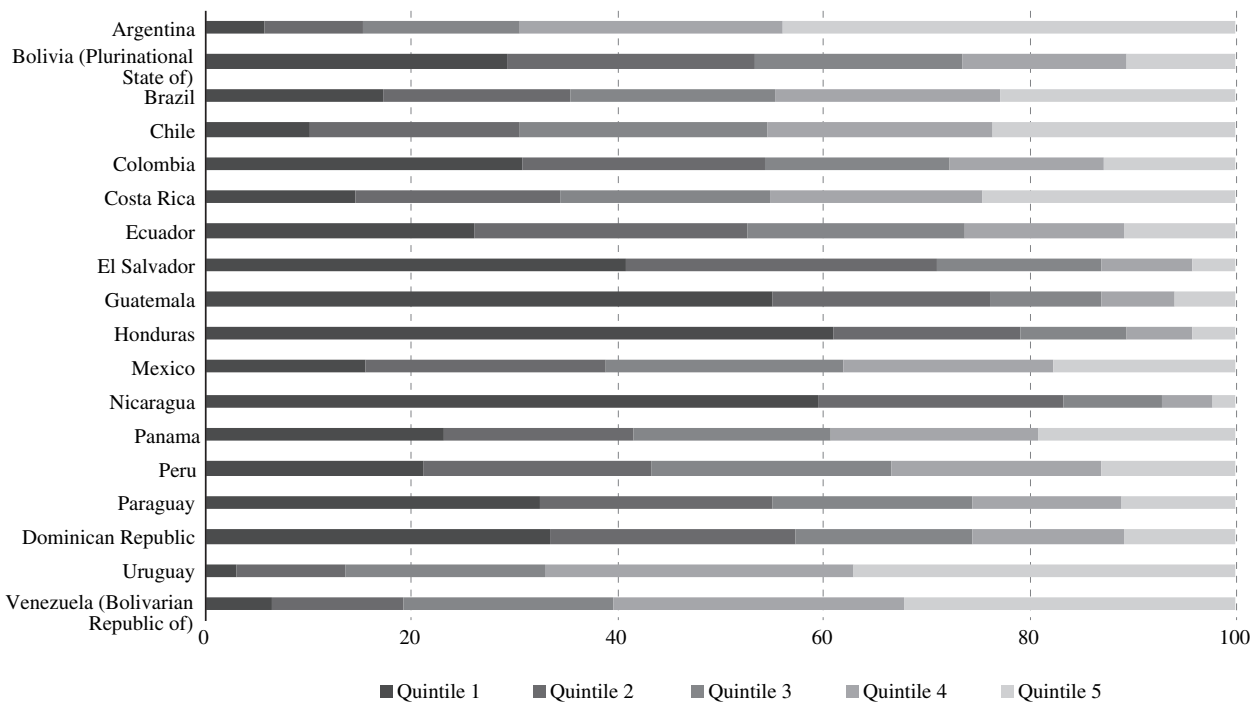

Source: Prepared by the authors, on the basis of World Bank, World Development Indicators, and household survey data from the respective countries.

Between 2002 and 2012, the average per capita income of the region's inhabitants, expressed in PPP, grew by $28 \%$. If income is measured in poverty lines, the growth in the period was 30\%. The strongest growth was at the bottom of the distribution, as illustrated in figure 7, which presents changes by decile and percentile. In terms of both PPP-adjusted income and income relative to the poverty line, it can be seen that the increase tails off up the income scale. In the terminology of Ravallion and Chen (2003), the growth incidence curve is indicative of pro-poor growth. This evolution is more marked in the case of PPP-adjusted income, which shows higher growth than poverty line-adjusted income for households in the bottom half of the income distribution. This higher growth in the incomes of individuals in the lower part of the regional distribution is thus a first indication of a decline in global inequality in the region.

Aggregated for the whole set of countries, this growth curve masks differences in the behaviour of groupings. This can be better appreciated if countries are clustered in four groups based on changes in their average incomes in the period considered (see figure 8). Changes in income and the classification of the countries into groups are presented in table A.3 of the annex. While some countries show a growth pattern that is clearly favourable to the poor (Argentina, the Bolivarian Republic of Venezuela, Paraguay and Uruguay are the extreme cases), in others the curve rises with income, with this showing stronger growth in the upper part of the distribution (Guatemala, Honduras and Nicaragua). Once again, both income vectors used yield similar results.

All the global inequality indicators calculated for the region show a similar pattern: inequality levels are higher when measured for Latin America as a whole than they are in most of the region's countries taken individually (see table 3), a finding also yielded by calculations of global inequality at the world level (see, for example, Anand and Segal, 2015; Lakner and Milanovic, 2013). In the second place, between 2002 and 2012, a period when inequality declined steadily in most of the region's countries, indicators of global inequality also dropped significantly, with the Gini coefficient, the Theil index and the 90/10 ratio all presenting a considerable decline. The Theil index fell by more than the Gini coefficient, since the former gives greater weight to what happens at the bottom of the distribution, which, as already seen, is where the greatest improvements occurred. The findings point in the same direction whether income is adjusted for PPP or for the poverty line. 
FIGURE 7

Latin America: changes in real incomes, 2002-2012

(Percentages)

A. By deciles of the regional distribution

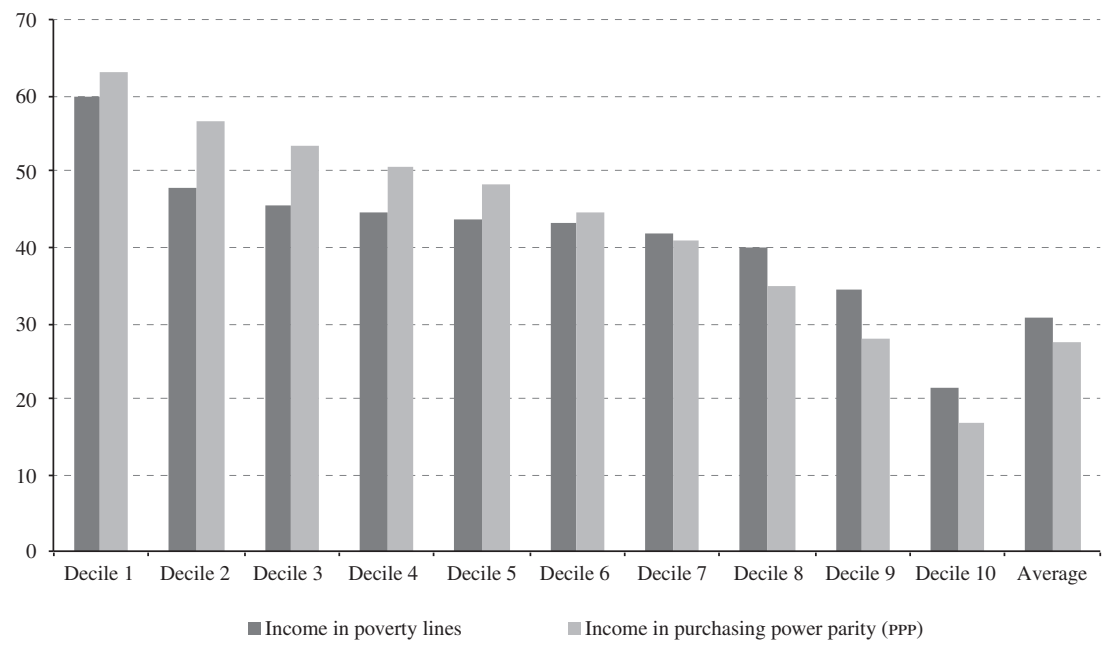

B. By percentiles of the regional distribution

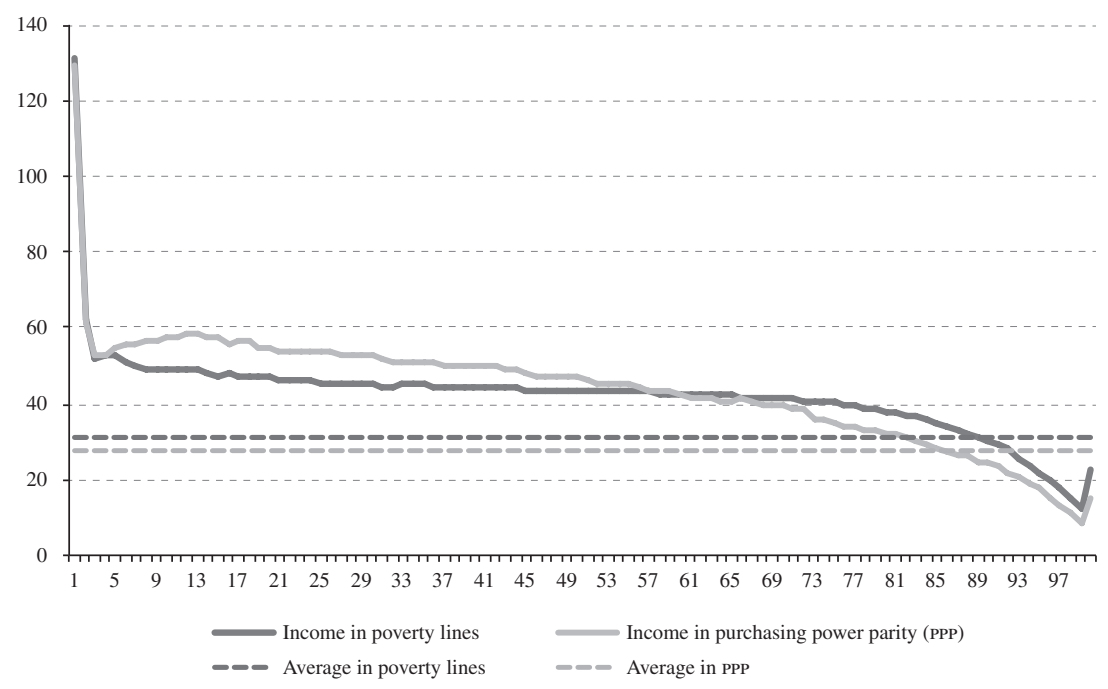

Source: Prepared by the authors, on the basis of World Bank, World Development Indicators, and household survey data from the respective countries. 
FIGURE 8

Latin America: income changes by country grouping, 2002-2012

A. Income in purchasing power parity (PPP)

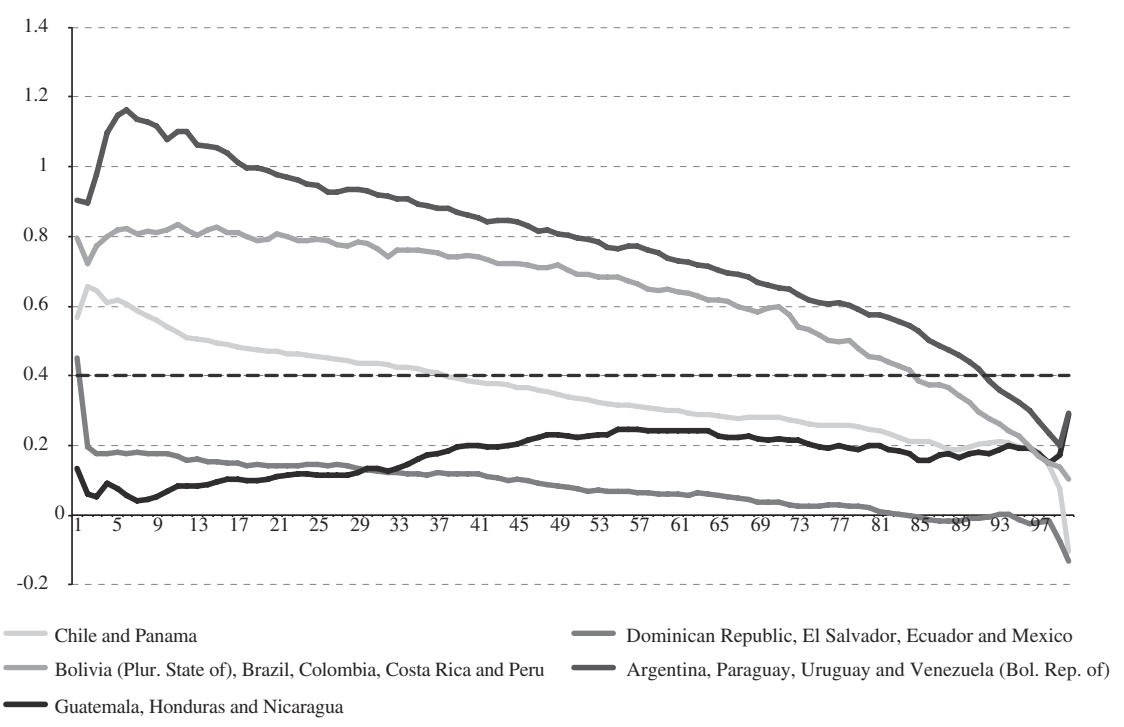

B. Income in poverty lines

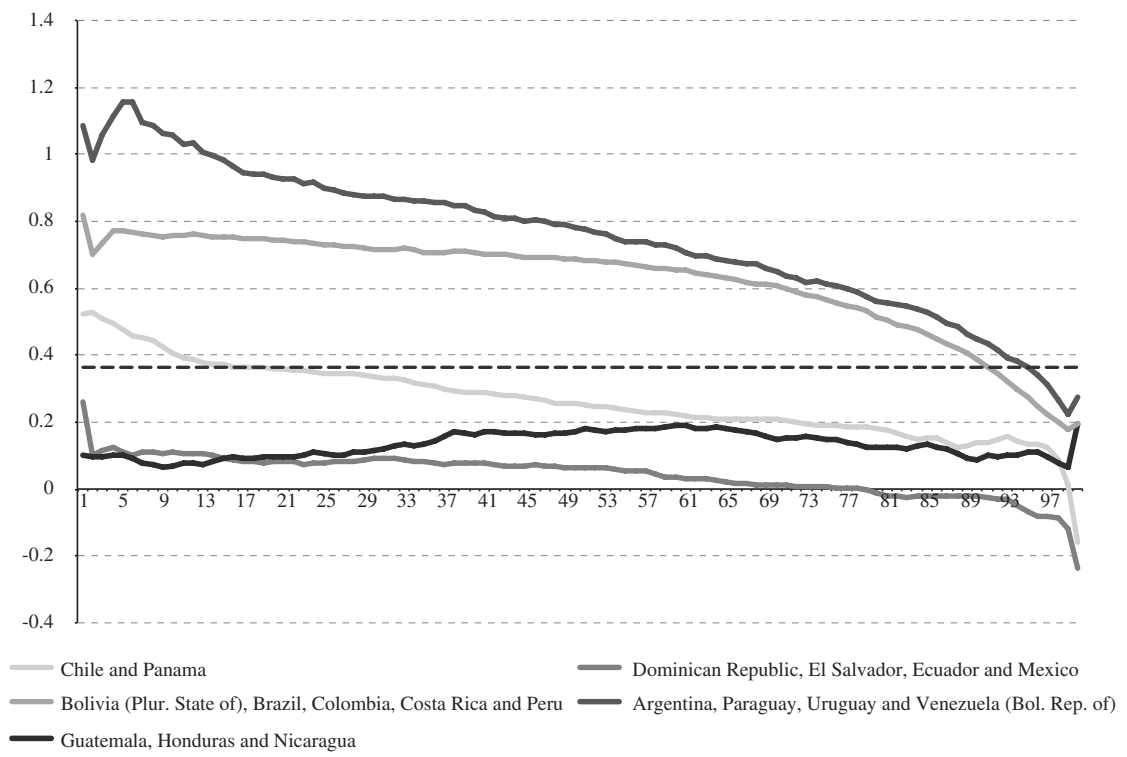

Source: Prepared by the authors, on the basis of World Bank, World Development Indicators, and household survey data from the respective countries. 
TABLE 3

Latin America: global inequality indices, 2002 and 2012

\begin{tabular}{|c|c|c|c|}
\hline Income in purchasing power parity (PPP) & 2002 & 2012 & Percentage change \\
\hline Gini coefficient & 0.587 & 0.539 & -8 \\
\hline Theil index & 0.760 & 0.658 & -13 \\
\hline \multicolumn{4}{|l|}{ Income in poverty lines } \\
\hline Gini coefficient & 0.580 & 0.546 & -6 \\
\hline Theil index & 0.768 & 0.703 & -8 \\
\hline $90 / 10$ ratio & 12.1 & 10.6 & -12 \\
\hline
\end{tabular}

Source: Prepared by the authors, on the basis of World Bank, World Development Indicators, and household survey data from the respective countries.

The income share captured by the richest percentiles in the region fell over the period, although the decline was very small, especially when PPP-adjusted income is taken (see figure 9). ${ }^{10}$ Once again, the results indicate that the gaps between people in the region as a whole are smaller than a decade ago, reaffirming the finding

10 This indicator is calculated on the basis of household survey information and consequently underestimates the true share of wealth captured by the highest percentiles, whose incomes tend not to be fully reflected in surveys of this type. of a decrease in regional inequality when this is considered globally.

Income inequality between individuals in the region can be broken down into inequality between countries and inequality within countries. The former is equivalent to considering inequality between all individuals in the region, assuming that each has an income equal to his or her country's average per capita income. Inequality within groupings or within countries, meanwhile, is a weighted average of national inequality indicators, the weights being each country's income as a share of the Latin American total.

Latin America: income shares captured by the top percentiles, 2002-2012

(Percentages)

A. Income in poverty lines

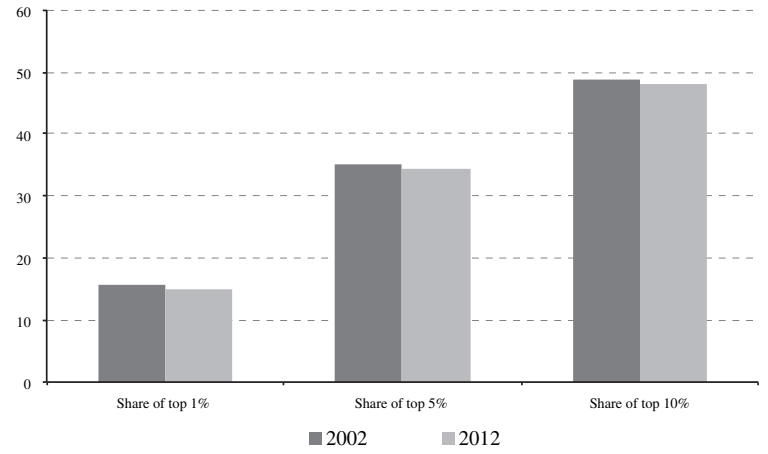

B. Income in purchasing power parity (PPP)

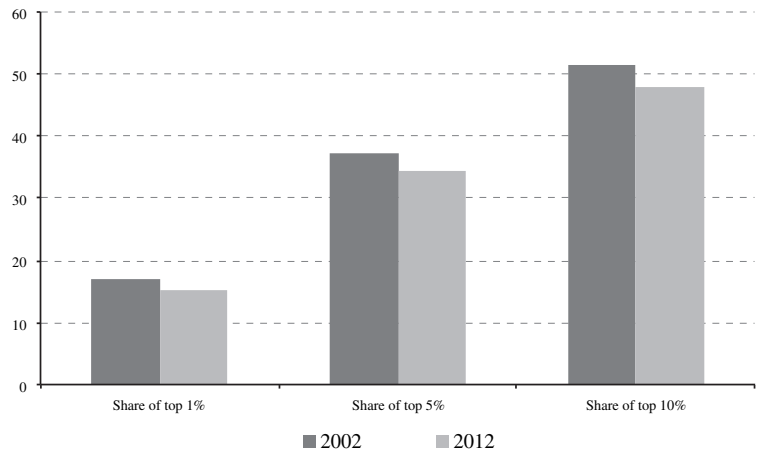

Source: Prepared by the authors, on the basis of World Bank, World Development Indicators, and household survey data from the respective countries.

The Theil index is used to display this decomposition of global inequality in the region, as it meets the requirements for this. A first aspect that emerges from this decomposition is that the bulk of regional inequality is within countries (see table 4). About $90 \%$ of global inequality in the region is the result of differences within countries. This finding is different from that yielded by worldwide decompositions, which indicate that between $80 \%$ and $90 \%$ of global inequality at the world level (depending on the measures and years taken) derives from differences in average incomes between countries (Anand and Segal, 2015). Restricting the analysis to 
Latin American countries reveals greater homogeneity between these, as might be expected from the smaller number of countries in the calculation; in turn, inequality within countries explains almost the entirety of regional inequality. These results indicate that the internal dynamics of countries, associated with their social, institutional and political situations, are more relevant to regional inequality than dynamics between countries (associated with migration or trade, for example). Again, it is worth recalling that each country's contribution to inequality depends mainly on its share of the total income of the region's households, so that Brazil and Mexico feature very prominently (see table A.4 of the annex).

A second aspect to be highlighted in this decomposition exercise is that the reduction in global inequality in the region during the period is mainly explained by the decline in inequality within countries. Once again, this result is strongly influenced by the distributive improvements that have taken place in Brazil and Mexico. The importance of inequality between countries (reflecting differences in average income by country) has consistently increased with the trend towards greater divergence in average incomes discussed in section V. Inequality between countries accounts for a small but growing share of global inequality in the region. These results indicate that the living conditions of Latin America's inhabitants are more egalitarian in relative terms now than a decade ago, although the differences between the countries' average incomes are greater. The findings regarding the decrease in global inequality in the region, and the absolute predominance of inequality within countries, with its deconcentrating effect, are similar to (although more pronounced than) those reported in Gasparini and others (2008) for the 1992-2006 period.

Decomposition of the Theil index for Latin America, 2002 and 2012

\begin{tabular}{|c|c|c|c|c|c|}
\hline & \multicolumn{2}{|c|}{ Theil index } & \multicolumn{2}{|c|}{$\begin{array}{l}\text { Importance of the components } \\
\text { (percentage share) }\end{array}$} & \multirow{2}{*}{$\begin{array}{c}\text { Percentage change } \\
2012-2002\end{array}$} \\
\hline & 2002 & 2012 & 2002 & 2012 & \\
\hline \multicolumn{6}{|c|}{ Income in poverty lines } \\
\hline Within countries & 72.4 & 63.2 & 94 & 90 & -13 \\
\hline Between countries & 4.5 & 7.1 & 6 & 10 & 60 \\
\hline Theil index & 76.8 & 70.3 & 100 & 100 & -8 \\
\hline \multicolumn{6}{|c|}{ Income in purchasing power parity (PPP) } \\
\hline Within countries & 72.9 & 61.7 & 95 & 88 & -15 \\
\hline Between countries & 3.1 & 4.1 & 4 & 6 & 33 \\
\hline Theil index & 76.0 & 65.8 & 100 & 100 & -13 \\
\hline
\end{tabular}

Source: Prepared by the authors, on the basis of World Bank, World Development Indicators, and household survey data from the respective countries.

\section{VII}

\section{Final comments}

Notwithstanding differences between countries, the income growth experienced by Latin American households in the last decade has been highest among households and individuals in the bottom stratum of the distribution. Global inequality in the region declined between 2002 and 2012 as a result, indicating that the living conditions of the inhabitants of Latin America were more equal at the end of those 10 years than at the start. These findings are robust to both price vectors used to compare income between countries.
Although the incomes of individuals in Latin America as a whole are less unequal now than a decade ago, this finding is the outcome of two opposing effects: a decline in inequality in most of the countries and a widening of the differences between the countries' average incomes. Although the second effect is very slight, it is apparent that widening income gaps between the region's countries can become a factor that works against the reduction of inequality from a regional perspective. 
ANNEX

TABLE A.1

Latin America (18 countries): distribution of the population by regional income quintiles $^{\mathrm{a}}, 2002$ and 2012

(Percentages)

\begin{tabular}{|c|c|c|c|c|c|c|c|}
\hline & & Quintile 1 & Quintile 2 & Quintile 3 & Quintile 4 & Quintile 5 & Total \\
\hline \multirow[t]{2}{*}{ Argentina } & 2002 & 14.1 & 17.1 & 19.1 & 22.7 & 27.1 & 100.0 \\
\hline & 2012 & 5.6 & 9.5 & 15.4 & 25.4 & 44.0 & 100.0 \\
\hline Bolivia (Plurinational State of) & 2011 & 29.1 & 24.1 & 20.1 & 16.0 & 10.6 & 100.0 \\
\hline \multirow[t]{2}{*}{ Brazil } & 2002 & 22.0 & 20.0 & 19.0 & 18.3 & 20.6 & 100.0 \\
\hline & 2012 & 17.3 & 18.0 & 19.9 & 21.9 & 22.9 & 100.0 \\
\hline Chile & 2011 & 10.0 & 20.4 & 24.2 & 21.8 & 23.6 & 100.0 \\
\hline \multirow[t]{2}{*}{ Colombia } & 2002 & 30.5 & 24.6 & 19.4 & 14.3 & 11.1 & 100.0 \\
\hline & 2012 & 30.8 & 23.4 & 18.0 & 15.0 & 12.8 & 100.0 \\
\hline \multirow[t]{2}{*}{ Costa Rica } & 2002 & 10.7 & 13.7 & 21.3 & 26.4 & 27.9 & 100.0 \\
\hline & 2012 & 14.4 & 20.0 & 20.4 & 20.5 & 24.7 & 100.0 \\
\hline \multirow[t]{2}{*}{ Dominican Republic } & 2002 & 20.8 & 22.5 & 22.4 & 19.5 & 14.7 & 100.0 \\
\hline & 2012 & 33.3 & 24.0 & 17.2 & 14.6 & 11.0 & 100.0 \\
\hline Ecuador & 2012 & 26.2 & 26.5 & 20.9 & 15.6 & 10.9 & 100.0 \\
\hline \multirow[t]{2}{*}{ El Salvador } & 2001 & 29.6 & 23.0 & 20.1 & 16.3 & 11.1 & 100.0 \\
\hline & 2012 & 40.7 & 30.3 & 15.8 & 9.0 & 4.3 & 100.0 \\
\hline \multirow[t]{2}{*}{ Guatemala } & 2002 & 31.4 & 27.1 & 17.1 & 14.0 & 10.5 & 100.0 \\
\hline & 2006 & 55.0 & 21.0 & 10.8 & 7.1 & 6.0 & 100.0 \\
\hline \multirow[t]{2}{*}{ Honduras } & 2002 & 53.6 & 19.9 & 13.0 & 8.3 & 5.3 & 100.0 \\
\hline & 2010 & 60.8 & 18.3 & 10.3 & 6.4 & 4.2 & 100.0 \\
\hline \multirow[t]{2}{*}{ Mexico } & 2002 & 8.3 & 17.7 & 22.0 & 26.2 & 25.8 & 100.0 \\
\hline & 2012 & 15.4 & 23.4 & 23.1 & 20.2 & 17.9 & 100.0 \\
\hline \multirow[t]{2}{*}{ Nicaragua } & 2001 & 51.0 & 24.0 & 13.2 & 7.7 & 4.2 & 100.0 \\
\hline & 2009 & 59.4 & 23.8 & 9.5 & 4.9 & 2.4 & 100.0 \\
\hline \multirow[t]{2}{*}{ Panama } & 2002 & 23.4 & 17.8 & 18.2 & 20.6 & 19.9 & 100.0 \\
\hline & 2011 & 23.1 & 18.4 & 19.1 & 20.0 & 19.4 & 100.0 \\
\hline \multirow[t]{2}{*}{ Peru } & 2001 & 29.5 & 24.2 & 21.0 & 15.7 & 9.6 & 100.0 \\
\hline & 2012 & 21.1 & 22.2 & 23.1 & 20.5 & 13.0 & 100.0 \\
\hline \multirow[t]{2}{*}{ Uruguay } & 2002 & 3.4 & 12.3 & 20.0 & 29.2 & 35.1 & 100.0 \\
\hline & 2012 & 3.0 & 10.4 & 19.4 & 30.1 & 37.1 & 100.0 \\
\hline \multirow[t]{2}{*}{ Venezuela (Bolivarian Republic of) } & 2002 & 11.1 & 15.4 & 21.2 & 25.3 & 27.0 & 100.0 \\
\hline & 2012 & 6.5 & 12.7 & 20.2 & 28.1 & 32.3 & 100.0 \\
\hline
\end{tabular}

Source: Prepared by the authors, on the basis of World Bank, World Development Indicators, and household survey data from the respective countries.

a In 2005 purchasing power parity (PPP) dollars. 
TABLE A.2

Latin America (18 countries): distribution of the population by regional income quintiles ${ }^{a}$

(Percentages)

\begin{tabular}{|c|c|c|c|c|c|c|c|}
\hline & & Quintile 1 & Quintile 2 & Quintile 3 & Quintile 4 & Quintile 5 & Total \\
\hline \multirow[t]{2}{*}{ Argentina } & 2002 & 23.2 & 19.5 & 19.1 & 19.3 & 18.9 & 100.0 \\
\hline & 2012 & 9.6 & 13.4 & 19.9 & 26.1 & 31.0 & 100.0 \\
\hline \multirow[t]{2}{*}{ Bolivia (Plurinational State of) } & 2002 & 38.5 & 21.4 & 15.4 & 13.7 & 10.9 & 100.0 \\
\hline & 2011 & 26.9 & 23.8 & 21.7 & 17.5 & 10.1 & 100.0 \\
\hline \multirow[t]{2}{*}{ Brazil } & 2002 & 18.4 & 17.0 & 18.0 & 20.8 & 25.7 & 100.0 \\
\hline & 2012 & 13.2 & 14.5 & 17.6 & 23.7 & 31.1 & 100.0 \\
\hline \multirow[t]{2}{*}{ Chile } & 2000 & 6.2 & 11.7 & 18.8 & 27.3 & 36.0 & 100.0 \\
\hline & 2011 & 6.6 & 13.5 & 21.9 & 27.7 & 30.3 & 100.0 \\
\hline \multirow[t]{2}{*}{ Colombia } & 2002 & 23.7 & 23.0 & 20.9 & 17.9 & 14.5 & 100.0 \\
\hline & 2012 & 24.3 & 22.2 & 20.6 & 18.1 & 14.7 & 100.0 \\
\hline \multirow[t]{2}{*}{ Costa Rica } & 2002 & 8.2 & 10.0 & 17.3 & 27.7 & 36.8 & 100.0 \\
\hline & 2012 & 12.1 & 16.2 & 21.3 & 23.3 & 27.0 & 100.0 \\
\hline \multirow[t]{2}{*}{ Dominican Republic } & 2002 & 22.2 & 21.2 & 21.2 & 20.0 & 15.4 & 100.0 \\
\hline & 2012 & 32.6 & 21.5 & 17.7 & 16.3 & 11.9 & 100.0 \\
\hline \multirow[t]{2}{*}{ Ecuador } & 2002 & 22.4 & 23.4 & 22.7 & 18.5 & 13.0 & 100.0 \\
\hline & 2012 & 22.3 & 25.2 & 23.8 & 18.1 & 10.6 & 100.0 \\
\hline \multirow[t]{2}{*}{ El Salvador } & 2001 & 24.6 & 21.4 & 20.9 & 19.7 & 13.4 & 100.0 \\
\hline & 2012 & 33.2 & 29.9 & 20.4 & 11.6 & 4.9 & 100.0 \\
\hline \multirow[t]{2}{*}{ Guatemala } & 2002 & 30.6 & 26.5 & 17.8 & 14.5 & 10.6 & 100.0 \\
\hline & 2006 & 44.9 & 23.7 & 14.4 & 9.9 & 7.0 & 100.0 \\
\hline \multirow[t]{2}{*}{ Honduras } & 2002 & 55.2 & 20.0 & 12.3 & 7.7 & 4.8 & 100.0 \\
\hline & 2010 & 58.8 & 18.3 & 11.7 & 6.9 & 4.2 & 100.0 \\
\hline \multirow[t]{2}{*}{ Mexico } & 2002 & 13.0 & 22.8 & 23.9 & 21.9 & 18.3 & 100.0 \\
\hline & 2012 & 25.7 & 28.0 & 22.3 & 14.1 & 9.9 & 100.0 \\
\hline \multirow[t]{2}{*}{ Nicaragua } & 2001 & 43.5 & 23.6 & 15.8 & 11.0 & 6.2 & 100.0 \\
\hline & 2009 & 46.8 & 25.9 & 15.5 & 8.0 & 3.8 & 100.0 \\
\hline \multirow[t]{2}{*}{ Panama } & 2002 & 19.0 & 15.5 & 18.0 & 22.1 & 25.4 & 100.0 \\
\hline & 2011 & 18.9 & 16.7 & 19.9 & 22.9 & 21.6 & 100.0 \\
\hline \multirow[t]{2}{*}{ Peru } & 2001 & 27.3 & 24.1 & 21.9 & 16.3 & 10.4 & 100.0 \\
\hline & 2012 & 18.0 & 21.3 & 24.7 & 22.7 & 13.3 & 100.0 \\
\hline \multirow[t]{2}{*}{ Paraguay } & 2001 & 31.9 & 24.3 & 19.5 & 14.7 & 9.7 & 100.0 \\
\hline & 2011 & 40.4 & 23.0 & 17.9 & 11.8 & 6.9 & 100.0 \\
\hline \multirow[t]{2}{*}{ Uruguay } & 2002 & 3.4 & 10.1 & 17.6 & 29.8 & 39.1 & 100.0 \\
\hline & 2012 & 3.4 & 8.9 & 18.3 & 32.6 & 36.9 & 100.0 \\
\hline \multirow[t]{2}{*}{ Venezuela (Bolivarian Republic of) } & 2002 & 23.7 & 21.7 & 20.8 & 19.3 & 14.5 & 100.0 \\
\hline & 2012 & 16.1 & 22.3 & 24.6 & 24.1 & 13.0 & 100.0 \\
\hline
\end{tabular}

Source: Prepared by the authors, on the basis of data from household surveys in the respective countries.

a Income in poverty lines. 
TABLE A. 3

Latin America (18 countries): country groupings and changes in per capita household income in purchasing power parity (PPP)

(Percentages)

\begin{tabular}{llr}
\hline Grouping & & Changes in per capita income in PPP ${ }^{\mathrm{a}}, 2002-2011$ \\
\hline 1 & El Salvador & -10 \\
1 & Dominican Republic & -2 \\
1 & Ecuador & 0 \\
1 & Mexico & 3 \\
2 & Guatemala & 6 \\
2 & Honduras & 7 \\
2 & Nicaragua & 7 \\
3 & Panama & 11 \\
3 & Chile & 16 \\
4 & Peru & 31 \\
4 & Costa Rica & 32 \\
4 & Brazil & 32 \\
4 & Bolivia (Plurinational State of) & 33 \\
4 & Colombia & 46 \\
5 & Venezuela (Bolivarian Republic of) & 52 \\
5 & Uruguay & 53 \\
5 & Paraguay & Argentina
\end{tabular}

Source: Prepared by the authors on the basis of World Bank, World Development Indicators, and household survey data from the respective countries.

a In purchasing power parity (PPP) dollars.

TABLE A. 4

Latin America (18 countries): contribution to intra-group inequality, 2002 and 2012

\begin{tabular}{|c|c|c|c|c|c|c|}
\hline & \multicolumn{3}{|c|}{2002} & \multicolumn{3}{|c|}{2012} \\
\hline & Theil index & $\begin{array}{l}\text { Percentage } \\
\text { income share }\end{array}$ & $\begin{array}{l}\text { Percentage } \\
\text { contribution to } \\
\text { intra-group } \\
\text { inequality }\end{array}$ & Theil index & $\begin{array}{l}\text { Percentage } \\
\text { income share }\end{array}$ & $\begin{array}{l}\text { Percentage } \\
\text { contribution to } \\
\text { intra-group } \\
\text { inequality }\end{array}$ \\
\hline Argentina & 0.487 & 5 & 4 & 0.322 & 6 & 4 \\
\hline Bolivia (Plurinational State of) & 0.742 & 1 & 1 & 0.391 & 1 & 1 \\
\hline Chile & 0.570 & 4 & 4 & 0.450 & 4 & 3 \\
\hline Colombia & 0.660 & 6 & 7 & 0.570 & 7 & 8 \\
\hline Costa Rica & 0.465 & 1 & 1 & 0.501 & 1 & 1 \\
\hline Dominican Republic & 0.533 & 2 & 1 & 0.420 & 1 & 1 \\
\hline Ecuador & 0.565 & 2 & 2 & 0.434 & 2 & 2 \\
\hline El Salvador & 0.505 & 1 & 1 & 0.368 & 1 & 0 \\
\hline Guatemala & 0.596 & 2 & 2 & 0.680 & 1 & 1 \\
\hline Honduras & 0.768 & 1 & 1 & 0.617 & 1 & 1 \\
\hline Nicaragua & 0.824 & 1 & 1 & 0.440 & 0 & 0 \\
\hline Panama & 0.612 & 1 & 1 & 0.529 & 1 & 1 \\
\hline Paraguay & 0.655 & 1 & 1 & 0.588 & 1 & 1 \\
\hline Peru & 0.619 & 4 & 4 & 0.404 & 5 & 4 \\
\hline Uruguay & 0.357 & 1 & 1 & 0.247 & 1 & 0 \\
\hline Venezuela (Bolivarian Republic of) & 0.400 & 3 & 2 & 0.273 & 4 & 2 \\
\hline
\end{tabular}

Source: Prepared by the authors, on the basis of World Bank, World Development Indicators, and household survey data from the respective countries. 


\section{Bibliography}

Alesina, A. and R. Perotti (1996), "Income distribution, political instability and investment", European Economic Review, vol. 40, No. 6, Amsterdam, Elsevier.

Alesina, A. and D. Rodrik (1994), "Distributive politics and economic growth", The Quarterly Journal of Economics, vol. 109, No. 2, Oxford University Press.

Anand, S. and P. Segal (2015), "The global distribution of income", Handbook of Income Distribution, vol. 2, Amsterdam, Elsevier. (2008), "What do we know about global income inequality?", Journal of Economic Literature, vol. 46, No. 1, Nashville, Tennessee, American Economic Association.

Alvaredo, F. and L. Gasparini (2015), "Recent trends in inequality and poverty in developing countries", Handbook of Income Distribution, A. Atkinson and F. Bourguignon (eds.), vol. 2, Amsterdam, Elsevier.

Atkinson, A. (2015), Inequality: What Can Be Done?, Cambridge, Massachusetts, Harvard University Press.

Azevedo, J. and others (2013), "Fifteen years of inequality in Latin America: how have labor markets helped?", Policy Research Working Papers, No. 6384, Washington, D.C., World Bank.

Barro, R. (2000), "Inequality and growth in a panel of countries", Journal of Economic Growth, vol. 5, No. 1, Springer.

Berry, A., F. Bourguignon and C. Morrison (1983), "The level of world inequality: how much can one say?", Review of Income and Wealth, vol. 29, No. 3, Wiley.

Bourguignon, F. and C. Morrison (2002), "Inequality among world citizens: 1820-1992", American Economic Review, vol. 92, No. 4, Nashville, Tennessee, American Economic Association.

Chen, S. and M. Ravallion (2010), "The developing world is poorer than we thought, but no less successful in the fight against poverty", Quarterly Journal of Economics, vol. 125, No. 4 Oxford University Press.

Cornia, G.A. (2010), "Income distribution under Latin America's new left regimes", Journal of Human Development and Capabilities, vol. 11, No. 1, Taylor \& Francis.

De la Torre, A., J. Messina and S. Pienknagura (2012), The Labor Market Story behind Latin America's Transformation, Washington, D.C., World Bank.

ECLAC (Economic Commission for Latin America and the Caribbean) (2014), Compacts for Equality: Towards a Sustainable Future (LC/G.2586(SES.35/3)), Santiago.

(2013), Social Panorama of Latin America 2013 (LC/G.2580), Santiago.

(2012), Social Panorama of Latin America 2010 (LC/G.2514-P), Santiago.

Feldstein, M. (1999), "Reducing poverty not inequality", The Public Interest, No. 137.

Gasparini, L. and others (2012), "Educational upgrading and returns to skills in Latin America. Evidence from a supply-demand framework, 1990-2010", cedLas Working Papers, No. 127, La Plata, Centre for Distributive, Labour and Social Studies (CEDLAS).
(2008), "Spatial welfare disparities in Latin America and the Caribbean", La Plata, Centre for Distributive, Labour and Social Studies (CEDLAS).

Gasparini, L. and P. Gluzmann (2012), "Estimating income poverty and inequality from Gallup World Poll: the case of Latin America and the Caribbean", Journal of Income Distribution, vol. 21 , No. 1 .

Lakner, C. and B. Milanovic (2013), "Global income distribution: from the fall of the Berlin Wall to the Great Recession", Policy Research Working Papers, No. 6719, Washington, D.C., World Bank.

López-Calva, L. and N. Lustig (2010), Declining Inequality in Latin America. A Decade of Progress?, Washington, D.C., Brookings Institution Press.

Milanovic, B. (2015), "Global inequality of opportunity: how much of our income is determined by where we live", Review of Economics and Statistics, vol. 97, No. 2, Cambridge, Massachusetts, The MIT Press.

(2012), "Global inequality recalculated and updated: the effect of new PPP estimates on global inequality and 2005 estimates", Journal of Economic Inequality, vol. 10, No. 1, Springer.

(2007), "Why We All Care about Inequality (but are Loath to Admit It)", Challenge, vol. 50, No. 6, Taylor \& Francis.

(2005), Worlds Apart: Measuring International and Global Inequality, Princeton, Princeton University Press.

Niño-Zarazúa, M., L. Roope and F. Tarp (2014), "Global interpersonal inequality: trends and measurement", WIDER Working Paper, No. 2014/004, World Institute for Development Economics Research (UNU-WIDER).

Persson, T. and G. Tabellini (1994), "Is inequality harmful for growth?", American Economic Review, vol. 84, No. 3, Nashville, Tennessee, American Economic Association.

Ravallion, M. and S. Chen (2003), "Measuring pro-poor growth", Economic Letters, vol. 78, No. 1, Amsterdam, Elsevier.

Ravallion, M., S. Chen and P. Sangraula (2009), "Dollar a day revisited", World Bank Economic Review, vol. 23, No. 2, Washington, D.C., World Bank.

Roberts, K. (2014), "The politics of inequality and redistribution in Latin America's post-adjustment era", Falling Inequality in Latin America. Policy Changes and Lessons, G.A. Cornia (ed.), Oxford University Press.

Roemer, J. (1998), Equality of Opportunity, Cambridge, Massachusetts, Harvard University Press.

Sala-i-Martin, X. (2006), "The world distribution of income: falling poverty and... convergence, period", Quarterly Journal of Economics, vol. 121, No. 2, Oxford University Press.

Schultz, T.P. (1998), "Inequality in the distribution of personal income in the world: how it is changing and why", Journal of Population Economics, vol. 11, No. 3, Springer. 